\title{
Comfort needs as perceived by hospitalized elders: an analysis under the light of Kolcaba's theory
}

\author{
Necessidade de conforto percepcionada por idosos hospitalizados: uma análise à luz da teoria de Kolcaba
}

Necesidad de comodidad experimentada por ancianos hospitalizados: un análisis a la luz de la Teoría de Kolcaba

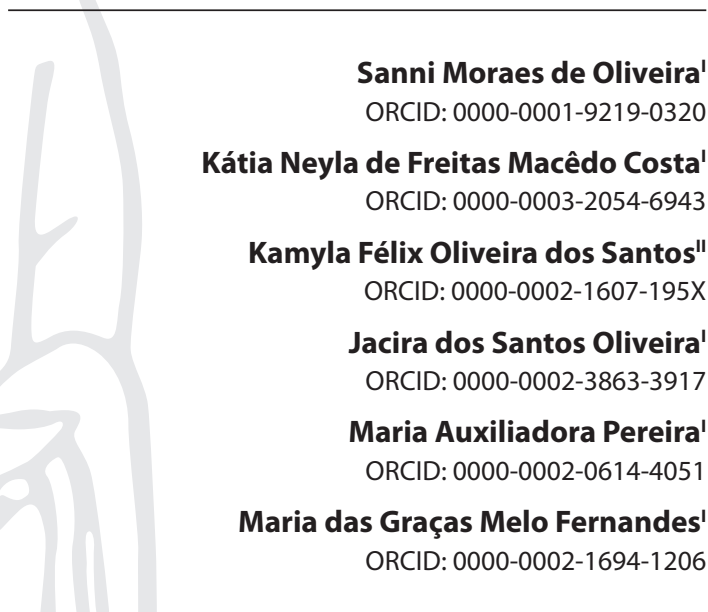

'Universidade Federal da Paraíba. João Pessoa, Paraíba, Brazil. "Centro Universitário de João Pessoa. João Pessoa,

Paraíba, Brazil.

How to cite this article:

Oliveira SM, Costa KNFM, Santos KFO, Oliveira JS, Pereira

MA, Fernandes MGM. Comfort needs as perceived by hospitalized elders: an analysis under the light of Kolcaba's theory. Rev Bras Enferm.2020;73(Suppl 3): e20190501. doi: http://dx.doi.org/10.1590/0034-7167-2019-0501

Corresponding author:

Sanni Moraes de Oliveira E-mail: sannidsm@gmail.com

EDITOR IN CHIEF:Dulce Barbosa ASSOCIATE EDITOR: Hugo Fernandes

Submission: 12-05-2019

Approval: 07-25-2020

\begin{abstract}
Objective: To reveal the Comfort needs as perceived by hospitalized elders, using Kolcaba's theory. Methods: Descriptive and qualitative study, with 11 elders hospitalized in a university hospital, aiming to identify their needs for Comfort. Results: Discourses were categorized in four thematic units: Physical, Environmental, Sociocultural, and Psychospiritual. In the Physical context, several subcategories were found, namely, Symptom Relief; Daily Life Activities; Hygiene and personal care; Diet; Sleep and rest. In the Environmental context, the Comfort was considered to be superior than in the elders' home; in the Sociocultural one, family bonds were found to become more distant, triggering feelings of missing one's family and isolation, in the Psychospiritual context, spirituality and religiosity stood out. Final considerations: The Comfort needs of the hospitalized elders enable one to reflect on nursing care, offering information to improve the quality of assistance and to attend to the real needs of the elderly.

Descriptors: Nursing; Nursing Theory; Elderly; Nurses Improving Care for Health System Elders; Patient Comfort.
\end{abstract}

\section{RESUMO}

Objetivo: Desvelar as necessidades de Conforto na percepção de pessoas idosas hospitalizadas, utilizando a Teoria de Kolcaba. Métodos: Estudo descritivo com abordagem qualitativa, com 11 idosos internados em um hospital universitário, com vistas a identificar necessidades de Conforto. Resultados: Os discursos foram categorizados em quatro unidades temáticas: Físico, Ambiental, Sociocultural e Psicoespiritual. No contexto Físico, foram identificadas as subcategorias de Alívio de Sintomas; Atividades de Vida Diária; Higiene e arranjo pessoal; Alimentação; Sono e repouso. No contexto Ambiental, o Conforto foi considerado superior ao do próprio lar. No Sociocultural, houve o afastamento dos vínculos familiares, despertando sentimentos de saudade e isolamento. No Psicoespiritual, evidenciou-se a espiritualidade e religiosidade. Considerações finais: As necessidades de Conforto dos idosos hospitalizados permitem refletir sobre os cuidados de enfermagem, fornecendo informações para qualificar a assistência e atender às necessidades reais da pessoa idosa.

Descritores: Enfermagem; Teoria de Enfermagem; Idoso; Cuidado de Enfermagem ao Idoso Hospitalizado; Conforto do Paciente.

\section{RESUMEN}

Objetivo: Desvelar las necesidades de la comodidad en la opinión de los ancianos hospitalizados usando la teoría de Kolcaba. Métodos: Estudio descriptivo con abordaje cualitativo, con 11 ancianos internados en un hospital de la universidad, con objetivo de identificar necesidades de la comodidad. Resultados: Los discursos han sido categorizados en cuatro unidades temáticas: Físico, Ambiental, Sociocultural y Psicoespiritual. En el Físico, se identificaron las subcategorías de Alivio de Síntomas; Actividades de la Rutina; Higiene y arreglos personales; Alimentación; Sueño y descanso. En el ambiental, la Comodidad ha sido considerada superior al del propio hogar. En el sociocultural, hubo el alejamiento de los lazos familiares, despertando sentimientos de nostalgia y aislamiento. En el Psicoespiritual, se evidenció la espiritualidad y religiosidad. Consideraciones finales: Las necesidades de Comodidad de ancianos hospitalizados permiten reflejar sobre los cuidados de enfermería, proveyendo información para cualificar la asistencia y atender a las necesidades reales de los ancianos. Descriptores: Enfermería; Teoría de Enfermería; Anciano; Atención de Enfermería para Ancianos Hospitalizados; Comodidad del Paciente. 


\section{INTRODUCTION}

Population has been aging systematically and gradually in developed societies, a phenomenon considered to be of great worldwide relevance ${ }^{(1)}$. Around the globe, there has been an absolute increase in the number of elders, which became 15.2 times larger from 1950 to 2020: in 1950, this population group included 202 million people, $8 \%$ of the total, while, in 2020, it increased to 1.1 billion, becoming $13.5 \%$, relatively speaking. According to projections, it is estimated that, in 2100 , they will be 3.1 billion of people, $28.2 \%$ of the world's population ${ }^{(2)}$.

Brazil is no different with regard to this dynamic, with a growth that is more pronounced than worldwide percentages from 1950 to 2020 , during which time its elderly population increased 27.6 times: the elder population, in 1950, was of 2.6 million, that is, $4.9 \%$ of the total; in 2020, it became 29.9 million, nearly $14 \%$ of the total of Brazilians; it is expected to reach 72.4 million elders in 2100, with a percentage of $40.1 \%$ of the total number of people in the country ${ }^{(2)}$.

This phenomenon generates specific demands for elders and leads to social and economic consequences, causing repercussions in health and in the quality of life of these people, generating new challenges associated with this process ${ }^{(1)}$.

Considering health needs, longevity is known to bring about multidimensional changes in the population, who ages and become more susceptible and vulnerable to chronic health conditions. These require continuous care, which is costly for the system, and are perceived as potentially disabling, leading to the need of complex health care. Additionally, these chronic conditions produce negative repercussions which can surface with the comorbidities, leading to a higher number of prolonged and constant hospitalizations ${ }^{(3)}$.

Hospitalization, despite being necessary to reestablish health, can generate anxiety, fear, and discomfort, showing itself as an unpleasant experience for a person, especially when elderly, due to their separation from the family environment and having to deal with the disease. This can easily lead the person to go through feelings of isolation, impotence, and solitude, since it tends to reinforce negative feelings expressed by a more passive and regressive posture ${ }^{(4)}$.

In this context, aiming to offer to the elder person an effective adaptation of assistance within the health-disease process, the nurse assumes a principal and privileged role in the process of care, which involves offering to the person cared for feelings of trust, safety, ease, and relief, through attitudes targeted at promoting well-being and Comfort ${ }^{(5)}$.

Among the contemporary theorists who study Comfort as a part of the process of caring in nursing, the contributions of Katharine Kolcaba stand out, since the researcher conceptualized and operationalized the phenomenon through the elaboration of the Comfort Theory. It is a middle-range predictive theory, and focuses on the importance of Comfort as a holistic result of the practice of nursing, highlighting the relevance of understanding it with a focus on multi-dimensionality ${ }^{(6)}$.

Kolcaba understands Comfort as an immediate experience of being, which is strengthened by the satisfaction of one's needs for relief, ease, and transcendence, in the four contexts of human experience - namely, the Physical, the Psychospiritual, the
Sociocultural, and the Environmental —, taking into account the uniqueness of each person ${ }^{(6)}$.

Considering the above, this investigation seeks to contribute with the production of knowledge that is a part of the field of nursing, since there are few studies that have Comfort as an object of analysis, especially considering as a reference Kolcaba's Theory of Comfort ${ }^{(6)}$, regarding the practice of caring in a hospitalization unit. This research is also important to raise, in health professionals, the awareness that Comfort is the result of actions that complement, improve the quality, and, in some circumstances, go beyond nursing care.

As a result, the relevance of this study is in its potential to generate important information about the object analyzed, offering, for the nurses, a greater knowledge with regard to the needs of Comfort for the elder person in their multidimensionality. Therefore, this study intends to answer the following research question: What are the needs of Comfort as perceived by hospitalized elders?

\section{OBJECTIVE}

To reveal the Comfort needs perceived by hospitalized elders, under the light of Kolcaba's Comfort Theory.

\section{METHODS}

\section{Ethical aspects}

During the entire research procedure, especially in the data collection stage, all ethical aspects that regulate researches involving human beings were respected, emphasizing the confidentiality of the information in accordance to Resolutions 466/2012 and $580 / 2018$ from the National Council of Health, Ministry of Health, Brazil. There was an evaluation by the Research Ethics Committee, and all prescriptions of Resolution 564/2017, from the National Council of Nursing, concerning the Ethics Code of Nursing Professionals, were respected. These are included in articles 16 to 18 , 56 to 58 , and 95 to 102 , which address all aspects of teaching, researching, and technical-scientific production.

\section{Theoretical-methodological framework}

According to Kolcaba's theory, Comfort is the immediate and holistic experience of being, which takes place through the satisfaction of the needs for relief, ease, and transcendence in the Physical, Psychospiritual, Sociocultural, and Environmental. It represents more than the absence of pain or other physical discomfort, it is an essential, multidimensional, and complex healthcare result ${ }^{(6)}$.

Katharine Kolcaba believes in the hypothesis that, in health contexts, the Comfort needs of people which have not yet been met are satisfied by nursing professionals through nursing measures or interventions. As a result, when Comfort is obtained, people feel strengthened and committed, adhere to health behaviors and healthy lifestyles, reaching, consequently, a holistic result ${ }^{(4)}$.

The conceptual model proposed by the theorist is based in needs that result from situations or stimuli that bring discomfort to the individual. Comfort needs must be identified, and nursing interventions should aim to positively displace discomfort, by using facilitating forces. Increasing Comfort indicates that 
negative tensions have diminished, leading to an improvement in the perception of the context ${ }^{(6)}$.

\section{Type of study}

The methodological structure includes a descriptive study, with a qualitative approach. It employs concepts that come from human and health researches, which do not seek to investigate a phenomenon, but to understand and interpret the meanings that it represents for those who experience it, searching for psychic and social representations, symbolizations, perceptions, points of view, perspectives, and life experiences ${ }^{(7)}$.

Regarding descriptive studies ${ }^{(8)}$, they are directed at the observation, at the description of a phenomenon of interest that is not well-known enough. They do not intervene in the setting of the research, but give support for its understanding. Therefore, the use of this method is justified, as it seeks to understand the Comfort needs as perceived by hospitalized elderly people, using Kolcaba's theory as a reference ${ }^{(6)}$.

\section{Methodological procedures}

To treat the data, Bardin's content analysis was used ${ }^{(9)}$. Considering this perspective, it was necessary to go through the following stages to operationalize this technique: a) organization of analysis; b) codification; c) categorization; and d) treatment of the results.

\section{Study setting}

The research was carried out in a clinical hospitalization unit, in a university hospital, where clinical treatments of the Single Health System (SUS) are carried out, including beds for the hospitalization of adult and elderly people from both sexes.

\section{Collection and organization of data}

Data was collected using the interview technique, which was conducted through the application of two instruments. The first one was made up of structured questions elaborated by the researcher, divided in two topics (I - Aspects that Qualify Elderly People, and II - Clinical Aspects). Thee specialists in the theme participated in an appearance validation of this instrument. The second instrument comprised semi-structured questions that aimed to learn the Comfort needs of elders, according to their perception. Later, the researcher submitted the instrument to a previous testing session, in which it was answered by three elders hospitalized in the clinical unit (who were not included in the sample of the study), in order to identify possible difficulties regarding the understanding of the questions in the instrument, thus, analyzing them. It should be noted that, after this procedure, the instrument was found to be viable for data collection.

The data collection period took place from November to December 2018. The data found from the answers of the elders was registered, and, later, transcribed in its entirety, exactly and accurately, by the researcher.

In addition to the instrument specified, a field journal was used, in which the researcher noted observations and impressions, found in the setting of the investigation, which were considered to be important to elucidate the study object.

\section{Work steps}

a) Analysis Organization - The material or corpus analyzed was made up by 11 interviews, which were transcribed and typed-in entirely. The statements of the participants were identified through the use of the letter C (for Comfort). In addition, a number was inserted corresponding to the order of the interviews, to preserve secrecy and guarantee the anonymity of those involved in the research.

b) Coding - The real data from the text, which constituted the corpus of the work, was systematically transformed in analysis excerpts or units, which corresponded to the small segments of the content or themes, based on which the elderly expressed their perceptions about the needs of Comfort.

c) Categorization - The thematic categories were preestablished and corresponded to the Comfort contexts indicated by Kolcaba's theoretical framework ${ }^{(6)}$ : Physical, Environmental, Sociocultural, and Psychospiritual. Considering this set of categories, as the units of analysis were grouped, subcategories that included the components regarding each context were established, in accordance to their similarities and differences.

In the Physical context, the following subcategories of Comfort needs ${ }^{(6)}$ were found:Symptom Relief; Daily Life Activities; Hygiene and personal care; Diet; Sleep and rest. In the Environmental context, the discourses showed subcategories related to the Natural or artificial elements of the hospital environment, in addition to the subcategory Privacy and Individuality. The Sociocultural context grouped the subcategories regarding Information and clarification, as well as the subcategories Autonomy, and Family and significant people. In the Psychospiritual context, the following subcategories were incorporated: Spirituality and religiosity, and Nursing support and care.

\section{Data analysis}

Once the categories and subcategories were established, they were analyzed using a qualitative approach, based on the theoretical framework adopted in the study.

\section{RESULTS}

\section{Thematic category: Physical context}

The Physical context of the Comfort experience, which emerges as a thematic category in this study, is related to the bodily feelings and includes homeostatic mechanisms and functions. The corresponding results involved this need, regarding the subcategories: Symptom Relief; Daily Life Activities; Hygiene and personal care; Diet; Sleep and rest.

Regarding Symptom relief, it can be noticed, in the statements, that the elders associate Comfort to the solving of the health problems in the hospital environment, be these related to pain or to the symptoms of the diseases:

We already leave our homes weakened. It was so much pain, and when I arrived here at the hospital, the pain went away. We grow 
when we find comfort! When we arrive and don't find it, we go down more and more. (C3)

Pain relief is intimately connected to the practice of nursing. It is a phenomenon of interest and a result that is expected during the implementation of care:

When I arrived here, I was really bad, the pain wouldn't stop, and now I'm better [...] / feel that embrace from the people here. When I'm in pain, I feel they worry about it and they do everything. (C6)

However, invasive, painful, and frequent procedures, such as the insertion of central and peripheral devices, are considered to be uncomfortable interventions that extrapolate the Physical domain:

Comfortable? I'm not, because of the prick holes [...] They pricked my finger really early, just now they pricked it here to take blood [...] I'm thinking a lot to put the access that was in my arm but was lost, now they'll put it in my neck. It's the only thing that's tormenting me, it hurts my head. (C8)

Regarding the subcategory Daily Life Activities, the main difficulties reported by the elders were related to the limitations of the chronic health conditions they confront in the context of their houses, and the way in which these activities should be conducted, imposed by the situation in which they find themselves as patients:

I'm a balanced person, I know I can get up, I'm so limited already and they want to tie me to a bed? I'm not bedridden, I'm just sick. (C7)

The subcategory Hygiene and personal care is one of the Comfort needs. Although the elders express the desire of remaining active, during their self-care they recognize how important, as a measure to increase Comfort, bed baths are, considering their real needs:

The nurses do everything that's good for me [...] They help me, soap me, arrange me, and dry me when I need it. (C4)

I couldn't even get up, my body would get too hot, when it was bath time, I felt that relief, I felt really good. (C10)

Concerning the subcategory Diet, the hospitalization is a rupture in the eating habits and routines of the elderly person, which can lead to dissatisfaction and the consequent non-acceptance:

Here, in the hospital, I've been eating well, but it isn't like my food at home. I think it's bad because it has no taste, but l eat it anyway. (C6)

For the participants of the study, well-prepared food, attending to the preferences of the patients, was considered to be a necessity for Comfort:

Everyday, the nutrition team asks how I'm eating and what I prefer. I say I want fish pirão [a Brazilian dish made of corn flour, sauces, and, in most cases, fish]. If it came, I'd be very happy. (C8)

Regarding the subcategory Sleep and Rest, in addition to being a physiological need of individuals, their quality is also an essential factor for achieving Comfort. In the statements of the elders, the discomfort regarding their physiological conditions can be noted:

Sleep I don't sleep, I go to the bathroom twice, or something like that, at night. Going back to sleep is very difficult. (C9)

\section{Thematic category: Environmental context}

The subcategories that emerged in this context were the Natural and/or artificial elements of the environment, and Privacy and Individuality of the patient. In this study, the elders did not mention being uncomfortable due to the hospital environment; they showed satisfaction and wellbeing with the environment and the elements that are part of it.

The environment here is good [...] The room is not like mine, but it's a room, there's sunlight, it's constantly cleaned, they give us new sheets every day, there's no noise. (C1)

Therefore, it can be noted that the elders, who need an adequate environment for the recovery of their health, find, in the hospital services, solutions to their problems, medical assistance, nursing care, and interaction with other patients and professionals. Also, sometimes they are confronted with difficult and precarious situations at home, which lead to abandonment. As a result, they consider this space to be Comfortable:

Inoticed that I don't feel good at home. I don't have all this comfort I have here. The house is small, made of earth, with six people in it, three children. Here it's completely different. (C11)

I feel comfortable here, while my house makes me feel bad, because I'm alone, left there. (C2)

The subcategory related to Privacy and individuality is indicated as necessary for the experience of Comfort in the hospital environment. In their statements, the hospitalized elders describe their personal space and territory in the collective wards as environments for social interaction:

I feel very well with my roommates, we always help each other, talk and have fun. (C4)

However, nurses must adequately classify collective nursing wards, to preserve the privacy and individuality of all, as the discourses below indicate:

When the colleague by our side feels bad, everyone comes to help them, they forget we're here by the side, we get really agitated. (C8)

\section{Thematic category: Sociocultural context}

In this category, the following themes emerged: Information and clarification; Autonomy; Family and Significant People.

In the subcategory related to Information and clarification, it was found that most elders had adequate information regarding the health treatment established; however, there were some exceptions, especially with regard to the technical terms used by the professionals, mentioned as barriers to the communication: 
The doctors inform me well about what they're doing and about the exam results too. I always know and that's very important for me, because I feel well taken care of. (C9)

Here they tell me everything nicely. Sometimes I don't understand well the difficult words. (C11)

Regarding the subcategory Autonomy, often times it can be noted that, when dealing with the established therapeutic conduct, professionals tend to be paternalistic, ignoring the autonomy of the elder and devaluing the importance of recognizing them as active subjects in the health-disease process.

About my health, only the doctors can say how I am. They are the ones who know, I know nothing. If I were to decide, I would have been discharged already, but I can't know... every day they measure my pressure, every day they take my blood, but we know nothing. (C1)

The thing that makes me uncomfortable the most is when I'm not heard, when I give a suggestion about my treatment, about my own wellbeing, and it's not accepted. I feel like a lonely person, voiceless, and that brings about a lot of discomfort. (C5)

I may not know the theory, but I know very well what the disease provokes in me. (C7)

The subcategory Family and significant people includes the presence and the support of family, as well as socialization. Elders have shown to be very worried about how much their disease/hospitalization fatigues their loved ones and is inconvenient to their routines.

This disease makes me sad. I'm not afraid of dying, I'm afraid of the suffering this disease can cause in me and in my relatives, especially my children, wearing them out. (C7)

According to the participants of the study, relatives have a significant role in treatment and rehabilitation. The attention provided by the family during visits, as well as the memories of grandchildren and/or children, are driving forces for the elders with regard to their recovery and to going back to their families as fast as possible, and they show to miss their family and feel isolated. Having the company of relatives during hospitalization was mentioned as a source of support and safety by the elders:

My daughter is everything for me, when she goes home at night, I keep wondering "Will she come back, my God? Did she leave angry with me?"I think: "I hope she comes back. She knows she's all I have." (C8)

My son gives me a lot of strength, he holds me, he kisses me, he's affective. He's adopted, but he's the best there is. (C4)

\section{Thematic category: Psychospiritual context}

This category is related to the Psychospiritual context, and the following subcategories were revealed: Spirituality and religiosity; Nursing support and care. It can be stated, according to the declarations of the interviewees, that the religious perspective was present in all discourses, showing the strong bonds of the elderly with a higher order and renewing their hopes toward behavioral changes:
I always say it like this: "Lord, I'll never open my mouth to say I'm alone, because the first person who is with me is You." Sometimes, when I'm sad, I hear a voice inside me: "Raise your head!" So, for me, there's no sadness. (C6)

The statements of the elders, therefore, show the importance of spirituality in this atypical situation they are facing in their lives:

My strength and my energy are over, but I believe that they will come back again, I trust the One up there [cries]. You only have strength and energy in your body when you're healthy; in my case, because of what I've been through, these things got distant, but I hope I can rebuild. My life is in the hands of God, He will solve this. (C10)

In the Psychospiritual dimension, the subcategory Nursing support and care was included, because the discourses showed that the nursing professionals have a meaningful role to encourage and give emotional strength to the elderly, helping them to cope with the situation they are in:

They all helped me deal with it. When one of them [nurse] left, another came in, and they just cheered me up more and more. They said I would get good [...] Everything they did for me was to help me, they gave me strength and courage [cries]. I had everything I needed here, thank God I was put in the right place. (C10)

The discourses of the elders in this study showed that, in the nursing-patient interaction, the aspect that provided the most Comfort was related to the good humor of the workers:

I like the nurses a lot, they know me, they make jokes. There's one who has a special place in my heart, she's very nice and I always have fun with her! I hugged her hard, I almost cried when I left. I like the treatment all of them give to me, they are careful and cheerful; when they make jokes with me, leven forget I'm sick. (C4)

Considering the above, it can be noted that nursing workers must have, as a guiding force of their care practice, good interpersonal relations, whether these involve the individual, the family, or the collective.

\section{DISCUSSION}

\section{Thematic category: Physical context}

In the subcategory Pain relief, pain is considered to be an individual and subjective experience, understood as an unpleasant sensation that can involve multidimensional aspects. Depending on them, each person has a threshold, which is determined by their experiences, including the unique ways in which each one attributes meaning to it, and their cultural models and values ${ }^{(10)}$. Although Comfort is not limited to the absence of pain ${ }^{(6)}$, the control or absence of pain-related symptoms is essential to achieve it, since the presence of pain and the feeling of pain are intrinsically linked to discomfort. It is possible to infer that the discomfort, such as pain, preoccupations, or suffering, significantly affect the physical and emotional structure of people, especially the elders.

Regarding the subcategory Daily Life Activities, individuals may have their ability to carry said activities out prejudiced due to fact 
that physiological changes caused by the aging process make them more susceptible to chronic diseases. Hospitalizations are a risk factor for the life of the elders, especially when repeated and long-lasting, and can generate negative consequences to their health. A pre-existing functional impairment can be worsened by the excess of bed rests, sleep deprivation, and iatrogenesis.

Hygiene and personal care, which form another subcategory, are necessary for Comfort. The measures considered to be associated to Comfort are those that provide a good appearance, promote protection against infections, and contribute for the promotion of the feelings of relief, lightness, self-esteem, and Comfort of the diseased ${ }^{(6)}$. According to what was previously displayed, the care with hygiene and personal care is an essential and private moment of interaction between the nursing worker and the patient. This process favors a better understanding of the patient with regard to the integrity of their skin and the inspection of abnormalities, including the knowledge about their anxieties and limitations ${ }^{(13-14)}$.

Regarding the subcategory Diet, it is known that the elderly must have balanced nutritional and hydro-electrolytic diets, since it directly influences their adequate metabolic and homeostatic functions, preventing diseases and complications ${ }^{(15)}$. As a result, for the elderly, the process of becoming diseased and sick is a stressing factor with regard to eating, since the meaning of this action starts to change, and, from then on, it becomes "nutrition". Therefore, the main objective of nutritional therapy in the hospital environment is to guarantee the amount and quality of the nutrients necessary to all individuals, and its standardization is essential to facilitate the activity of the nutritionist and help treating hospitalized patients ${ }^{(14)}$.

Regarding the subcategory Sleep and Rest, in addition to being a physiological need of individuals, its quality also corresponds to an essential factor for obtaining Comfort. Many alterations provoked by the natural course of aging prejudice the quality of sleep in the elderly. The most frequent are: the superficiality and the increase in the number of interruptions during sleep; and their duration. In addition to these, situations such as hospitalization, changes in the environment, medication schedules, and environmental barriers, can lead to sleep deprivation, making the fragmentation worse ${ }^{(5-16)}$.

\section{Thematic category: Environmental context}

Regarding positive environmental conditions, the Comfort of the environment and of the ward includes everything that can be manipulated by the nurses to promote $i^{(6)}$.

The subcategory Natural and/or artificial elements of the environment is related to the interaction and perception of the individual about the natural or artificial elements of the place where the patient is, including its physical structure, color, noise, lighting, temperature, cleaning of the ward, and Comfort of the bed. The environment may also have a greater meaning, transcending its physical elements. It represents a space of harmony and wellbeing which makes the environment calm, embracing, and is essential for the holistic Comfort of the elderly ${ }^{(14-17)}$.

Privacy and individuality, indicated by another subcategory, are shown to be necessary for the experience of Comfort in the hospital environment ${ }^{(6)}$. Considering this, during hospitalization, the elder may feel useful by helping other patients, sharing experiences, and practicing solidarity. It stands out that respect to privacy is one of the needs and a right of human beings - in this case, the right to preserve their bodies from being exposed and manipulated by others. In the hospital environment, the lack of privacy is characterized by changes in the physical space without the permission of the elder and due to the exposure of their body and of intimate body parts during procedures. The impact of these situations may be diminished through adaptations in the physical structure, using folding screens and avoiding unnecessary exposure of the body parts during procedures ${ }^{(18)}$.

\section{Thematic category: Sociocultural context}

Comfort is also generated when patients are well-informed about their health situation ${ }^{(6)}$. The subcategory associated with Information and clarification permeates the relation between the health professional and the patient and, currently, is undergoing a change from a paternalistic paradigm to one focused on informed consent, in which the patient becomes an active subject of the health-disease process: their decisions and their autonomy are not taken into account ${ }^{(19)}$.

Regarding the subcategory Autonomy, often times it can be noted that, when dealing with the established therapeutic conduct, professionals tend not to consider the decisions of the elders as related to their health and life, imposing conditions on their freedom of choice, inducing or preventing them from actively participating in the making of decisions that affect their health, which, especially with regards to the body, is an unacceptable violation of the rights of any individual ${ }^{(20)}$.

The subcategory Family and significant people includes the presence and the support of family, as well as socialization. Considering the Comfort needs of the hospitalized elder, this domain is understood as an important and decisive resource to understand the situation they experience, and is the unit in which the interpersonal needs are contemplated ${ }^{(15)}$.

The health-disease process, for the elderly and their relatives, is an unpleasant situation, leading to the need of changes in the life habits and increasing the distance between the elder and their family or other significant persons, easily generating feelings of anxiety and discomfort. The elder who is likely to be hospitalized, be it for a short or long time, for therapeutic treatment, must cope with emotional stress. They perceive themselves as weak beings, dependent and helpless, when confronted with the constraints imposed to them by life. It is possible to identify many different feelings that they easily externalize to those around them, among which are sadness and suffering ${ }^{(21-22)}$.

\section{Thematic category: Psychospiritual context}

This category is related to the Psychospiritual context, and the following subcategories were revealed: Spirituality and religiosity; Nursing support and care.

Understanding Spirituality and religiosity as an aspect with a strong impact, both individual and collective, especially for the elderly, is one of the needs identified. It has a very direct relation with the health-disease process with regard to the relief of 
emotional tension, Comfort, consolation, search for meaning, search for intimacy, social interaction, understanding of oneself, and search for the sacred ${ }^{(6)}$.

The subcategory Nursing support and care, included in the Psychospiritual dimension, is related to essential aspects of humanized assistance, which is the guiding principle of the ethics of caring. Therefore, the essential attributes are related to carefully listening to the other, nurse with words, with gestures, to be present in one's pain and suffering, being a part of a strategy to cope with the health-disease process of the individuals ${ }^{(23)}$.

The discourses of the elders in this study made it clear that good humor is one of the types of nursing care that give the most Comfort, which was often mentioned in the relation between nurses and the elderly as an expression of empathy, happiness, or even in more tense situations, occupying a special place in the interaction, bringing relevant positive effects in the wellbeing and psychological Comfort of the elderly ${ }^{(13)}$.

Considering the above, the affective-expressive dimension, as a result, must be enhanced and encouraged in the therapeutic actions of care, until a relationship of trust can be built through caring, understanding, respecting one's silence, listening, talking, stimulating, encouraging, and having good humor ${ }^{(19)}$.

\section{Study limitations}

This research was carried out in a university hospital, meaning its data should not be generalized. In addition, it is essential to consider the particularities of each elder from their unique perspective.

\section{Contributions to the Field of Nursing}

It has been made clear that the assumptions of the theorist are essential to understand the discourses and foster the idea that nurses have a principal role with regard to a practical approach of Comfort. Although patients express a comfortable situation $a$ priori, it is necessary to understand its multidimensionality, since Comfort is a holistic outcome and generates posterior results, be them for the patient, as it brings more satisfaction through the attention and adherence to the therapeutic plan, or for nursing workers, as it generates, for the institution relations that are effective, stronger, and offer better value for money.

\section{FINAL CONSIDERATIONS}

Based on the data obtained from this study and analyzed based on Kolcaba's Comfort Theory, the objectives of the investigation were achieved, revealing the individual multidimensionality and variability of the phenomenon of Comfort, as experienced by elderly hospitalized people. It can be noted that hospitalization was considered, by most interviewees, as a necessary and important step, being responsible, especially, for the reestablishment of health.

Consequently, the use of a nursing theory to recognize the dimensions of Comfort and the needs of Comfort of the elders make it possible to reflect about nursing care, providing information for critical thought, clinical judgment, and decision making, which give support to the planning of nursing results and interventions. As a result, promoting a holistic and integral interaction, capable of attending to the real needs of the person who is aging, is an objective sought to improve the quality of assistance, teaching, and research.

\section{ACKNOWLEDGMENT}

This article stems from the master's degree dissertation "Need for comfort perceived by hospitalized elderly people: an analysis in the light of Kolcaba's theory", presented to the Nursing Postgraduation Program from the Universidade Federal da Paraíba (PPGENF-UFPB), to which we are deeply grateful.

\section{REFERENCES}

1. Abreu DROM, Novaes ES, Oliveira RR, Mathias TAF, Marcon SS. Fall-related admission and mortality in older adults in Brazil: trend analysis. Cien Saude Colet. 2018;23(4):1131-41. doi: 10.1590/1413-81232018234.09962016

2. United Nations, Department of Economic and Social Affairs, Population Division. World Population Prospects [Internet]. 2019[cited 2019 Nov 30]. Available from: https://population.un.org/wpp2019/Publications/

3. Coutinho MLN, Samúdio MA, Andrade LM, Coutinho RN, Silva DMA. Perfil sociodemográfico e processo de hospitalização de idosos atendidos em um hospital de emergências. Rev Rene. 2015;16(6):908-1005. doi: 10.15253/2175-6783.2015000600018

4. Silva JMC, Ribeiro PPSV. Estratégias de autocuidado das pessoas com doença oncológica submetidas a quimioterapia/radioterapia e a sua relação com o conforto. Enferm Glob [Internet]. 2015[cited 2019 Nov 30]; 14(37):372-383. Available from: http://scielo.isciii.es/pdf/eg/v14n37/pt_revision2.pdf

5. Lima JVF, Guedes MVC, Silva LF, Freitas MC, Fialho AVM. Utilidade da teoria do conforto para o cuidado clínico de enfermagem à puérpera: análise crítica. Rev Gaúcha Enferm. 2016;37(4):e65022. doi: 10.1590/1983-1447.2016.04.65022

6. Kolcaba KY. Comfort theory and practice: a vision for holistic health care and research. New York: Springer; 2003. 288p.

7. Stake RE. Pesquisa qualitativa: estudando como as coisas funcionam. Porto Alegre: Penso; 2011. 263p.

8. Minayo MCS. O Desafio do Conhecimento: Pesquisa Qualitativa em Saúde. 10. ed. São Paulo: HUCITE; 2013. 408p.

9. Bardin L. Análise de conteúdo. São Paulo: Edições 70; 2011. 229p.

10. Correa RGCF, Santos RAAS, Rolim ILTP, Coutinho NPS. Atenção no cuidado ao idoso: infantilização e desrespeito à autonomia na assistência de enfermagem. Rev Pesq Saúde [Internet]. 2016[cited 2019 Nov 30];17(3):179-83. Available from: http://www.periodicoseletronicos.ufma. br/index.php/revistahuufma/article/view/6793/4335. 
11. Melo BRS, Diniz MAA, Casemiro FG, Figueiredo, LC, Santos-Orlandi AA, Haas VJ, et al. Avaliação cognitiva e funcional de idosos usuários do serviço público de saúde. Esc Anna Nery. 2017;21(4):1-8. doi: 10.1590/2177-9465-ean-2016-0388

12. Wietzke M, Hopp MS, Wagner LE, Fagundes JGS, Cardoso DM, Paiva DN. Comparação das atividades básicas de vida diária entre idosos hospitalizados e hígidos da região sul do Brasil. Rev Unisc. 2017;18(4):1-5. doi: 10.17058/cinergis.v18i4.9415

13. Pontífice-Sousa P, Marques RMD, Ribeiro PM. Geriatric care: ways and means of providing comfort. Rev Bras Enferm. 2017;70(4):830-7. [Thematic Edition "Good Practices: Fundamentals of care in Gerontological Nursing"] doi: 10.1590/0034-7167-2016-0636

14. Nascimento ERP, Silva SG, Souza BC, Souza DD, Netto AG. Ambiência de uma emergência hospitalar para o cuidado ao idoso: percepção dos profissionais de enfermagem. Esc Anna Nery. 2015;19(2):338-42. doi: 10.5935/1414-8145.20150046

15. Sousa ICP, Silva AG, Quirino ACS, Neves MS, Moreira LR. Perfil de pacientes dependentes hospitalizados e cuidadores familiares: conhecimento e preparo para as práticas do cuidado domiciliar. Rev Min Enferm. 2014;18(1):164-80. doi: 10.5935/1415-2762.20140013

16. Monteiro NT, Ceolim, MF. Qualidade do sono de idosos no domicílio e na hospitalização. Texto Contexto Enferm. 2014;23(2):356-64. doi: 10.1590/0104-07072014000190013

17. Góis JA, Freitas KS, Kolcaba K, Mussi FC. Cross-cultural adaptation of the General Comfort Questionnaire to Brazilian patients with myocardial infarction. Rev Bras Enferm. 2018;71(6):2998-3005. doi: 10.1590/0034-7167-2017-0557

18. Rosa PH, Beuter M, Benetti ERRB, Bruinsma JL, Venturini L, Backes C. Estressores vivenciados por idosos hospitalizados na perspectiva do Modelo de Sistemas de Neuman. Esc Anna Nery. 2018;22(4):e20180148. doi: 10.1590/2177-9465-ean-2018-0148

19. Tavares DI, Staullbaum JH, Pedroso H, Badaró AFV. Relação entre o profissional de saúde e o paciente idoso: questões bioéticas. Rev Cien Saúde Vitalle. 2017;29(2):107-15. doi: 10.14295/vittalle.v29i2.7684

20. Paranhos DGAM, Albuquerque A. A autonomia do paciente idoso no contexto dos cuidados em saúde e seu aspecto relacional. Rev Dir Sanit [Internet]. 2018[cited 2019 Nov 30];19(1):32-49. Available from: https://periodicos.furg.br/vittalle/article/view/7684/5019

21. Souza MMS. Arruda AJCG, Rodrigues FA, Silva GM, Santos FS, Vasconcelos DIB. Sentimentos de idosos hospitalizados pelo câncer: expectativas sobre alta hospitalar e a influência familiar. Rev Enferm UFPE. 2016;10(10):3720-6. doi: 10.5205/1981-8963-v10i10a11436p3720-3726-2016

22. Leite MT, Schons VF, Silva LAA, Muller LA, Pinno C, Hildebrandt LM. A hospitalização em unidade de terapia intensiva na voz de idosos e familiares. Estud Interdiscipl Envelhec [Internet]. 2015[cited 2019 Nov 30];20(2):535-49. Available from: https://seer.ufrgs.br/RevEnvelhecer/ article/view/46060/35456

23. Oliveira ALB, Menezes TMO. The meaning of religion/religiosity for the elderly. Rev Bras Enferm. 2018;71(suppl2):770-6. [Thematic Issue; Health of the Elderly]. doi: 10.1590/0034-7167-2017-0120 